\title{
Challenges before Indian SME'S for the Implementation of Lean Six Sigma for Scrap Reduction: A Review
}

\author{
Harsimran Singh Sodhi ${ }^{1}$, Bikram Jit Singh ${ }^{2}$, Doordarshi Singh ${ }^{3}$ \\ ${ }^{I}$ (Ph. D. Research Scholar, Department of Mechanical Engineering, I K Gujral PTU Jalandhar, India) \\ ${ }^{2}$ (Prof., Department of Mechanical Engineering, MMU Sadopur, India) \\ ${ }^{3}$ (Asst Prof, Department of Mechanical Engineering, BBSBEC Fatehgarh Sahib, India)
}

\begin{abstract}
Present research paper puts light on the current challenges faced by Indian SME's for the implementation of Lean Six Sigma for the purpose of scrap reduction. Global scenario of SMEs and various schemes offered by the governments for their upgradation is also discussed in this paper. From the detailed literature survey it has been noticed that a number of challenges have been faced by the SME's while the implementation of Lean Six Sigma.
\end{abstract}

Keywords - LEAN, Six Sigma, Small and Medium Enterprises (SME's)

\section{INTRODUCTION}

Small and Medium Enterprises (SMEs) are playing an important role in the economic growth of India. As per available data SMEs are contributing 18\% in the GDP growth of India (FY 2014-2015). SMEs are also a source of employments for the 50\% of Indian population. Today SMEs are flourished in well-organized clusters based manner (Mandar et al., 2014). SMEs are those industrial organizations whose number of employees and the annual turnover falls under a certain limit. According to newly enacted MSME Development Act 2006, which is effective from October 2, 2006; the enterprises are classified according to the following criteria (Rodriguez et.al. 2007). The main barrier in the growth of SMEs is the optimum utilization of available resources. Even National Manufacturing Competiveness Council (NMCC) has proposed the various schemes for developing the global competitiveness of Indian SMEs but still they are facing huge losses due to wastage of available resources.

TABLE I. Types of Enterprises in India (Source: Rodriguez et.al. 2007)

\begin{tabular}{|c|c|c|}
\hline $\begin{array}{c}\text { Type of } \\
\text { Enterprise }\end{array}$ & $\begin{array}{c}\text { Investment in plant } \\
\text { and Machinery engaged in production of } \\
\text { goods }\end{array}$ & $\begin{array}{c}\text { Investment in equipment } \\
\text { engaged in providing or rendering of } \\
\text { services }\end{array}$ \\
\hline $\begin{array}{c}\text { Micro } \\
\text { enterprise }\end{array}$ & $\begin{array}{c}\text { Does not exceed 25 } \\
\text { Lakh rupees }\end{array}$ & $\begin{array}{c}\text { Does not exceed 10 Lakh } \\
\text { rupees }\end{array}$ \\
\hline $\begin{array}{c}\text { Small } \\
\text { enterprise }\end{array}$ & rupees, but does not exceed 5 Crore rupees & $\begin{array}{c}\text { More than 10 Lakh rupees, } \\
\text { but does not exceed 2 } \\
\text { Crore rupees }\end{array}$ \\
\hline $\begin{array}{c}\text { Medium } \\
\text { enterprise }\end{array}$ & rupees but does not exceed 10 Crore rupees & $\begin{array}{c}\text { More than 2 Crore rupees } \\
\text { but does not exceed 5 } \\
\text { Crore rupees }\end{array}$ \\
\hline
\end{tabular}

\section{SMEs: GLOBAL SCENARIO}

Small and Medium Enterprises are playing a vital role in the manufacturing sector of various developing and developed countries of world. As per Lozzi (2008), SMEs of any country are having a strategic importance in economic growth because of their considerable contribution in terms of production, sales and development. Presently 
IOSR Journal of Mechanical and Civil Engineering (IOSR-JMCE)

e-ISSN: 2278-1684, p-ISSN: 2320-334X

the status of SMEs of various major countries of the world is mentioned in table no 2 below.

TABLE II Global Scenario of SMEs

\begin{tabular}{|c|c|l|}
\hline S.No & Country & \multicolumn{1}{c|}{ Scenario of SMEs } \\
\hline 1 & $\begin{array}{c}\text { United } \\
\text { States }\end{array}$ & $\begin{array}{l}\text { Units are directly benefitted by the government policies. There is direct cash flow } \\
\text { by government to enhance the quality of the SMEs. As per Small Business Act } \\
\text { the units having anticipated value of greater than US\$2,500 but less than } \\
\text { US\$100,000 are considered for small business concerns only. }\end{array}$ \\
\hline 2 & $\begin{array}{c}\text { Latin } \\
\text { America }\end{array}$ & $\begin{array}{l}\text { Recently Latin America also started focusing on SMEs as they are providing } \\
\text { employment to a larger part of population }\end{array}$ \\
\hline 3 & $\begin{array}{c}\text { Taiwan and } \\
\text { Hong Kong }\end{array}$ & $\begin{array}{l}\text { In 2005, Hong Kong was having almost 270, 000, SMEs giving employment to } \\
\text { approx. 50\% of population i.e. employment opportunities to 1.2 million people. }\end{array}$ \\
\hline 5 & China & $\begin{array}{l}\text { China is having 10 millions of Urban and rural SMEs and they contributes 60\% of } \\
\text { Chinas industrial output }\end{array}$ \\
\hline & Indian & $\begin{array}{l}\text { As per the socio economic model of India role of SMEs was meant for to generate } \\
\text { foreign exchange, providing jobs and to contribute in earning the foreign } \\
\text { exchange but due to improper implementation of various govt. policies they failed } \\
\text { to achieve the desired targets. }\end{array}$ \\
\hline
\end{tabular}

\section{GOVERNMENT SCHEMES TO UPGRADE SMES}

Indian government is working towards the up gradation of SMEs, therefore Ministry of Micro Small and Medium Enterprises had launched a number of schemes in order to enhance the condition of Indian SMEs. Some of the important schemes are listed in the table no 3 below.

TABLE III. Government Policies to assist SMEs

\begin{tabular}{|c|l|l|}
\hline S.No & \multicolumn{1}{|c|}{ Scheme } & \multicolumn{1}{c|}{ Brief } \\
\hline 1 & $\begin{array}{l}\text { Micro \& Small Enterprises } \\
\text { Cluster Development } \\
\text { Program (MSE-CDP) }\end{array}$ & $\begin{array}{l}\text { This scheme has been adopted for the development of clusters in order to } \\
\text { enhance the competitiveness of SMEs. Main objective of this scheme is to } \\
\text { support the sustainability and growth of SMEs in terms of quality, skills } \\
\text { and technology. }\end{array}$ \\
\hline 2 & $\begin{array}{l}\text { National Manufacturing } \\
\text { Competitiveness Program } \\
\text { (NMCP) }\end{array}$ & $\begin{array}{l}\text { Various plans have been launched under NMCP such as design of mini tool } \\
\text { rooms, opening of new design clinics and marketing support for SMEs }\end{array}$ \\
\hline 3 & $\begin{array}{l}\text { Enabling Manufacturing } \\
\text { through Quality Management } \\
\text { Standards and Quality } \\
\text { Technology Tools }\end{array}$ & $\begin{array}{l}\text { Main objective of this scheme is to enable the SMEs to adopt the latest } \\
\text { Quality Management standards and to use latest quality tools to improve } \\
\text { the quality. }\end{array}$ \\
\hline 4 & $\begin{array}{l}\text { Lean Manufacturing } \\
\text { Competitiveness Scheme for } \\
\text { MSMEs }\end{array}$ & $\begin{array}{l}\text { The main objective of this scheme is the application of various Lean } \\
\text { Manufacturing tools in order to improve the manufacturing competitiveness }\end{array}$ \\
\hline
\end{tabular}




\begin{tabular}{|c|l|l|}
5 & $\begin{array}{l}\text { Design Clinic Scheme for } \\
\text { design expertise to MSMEs } \\
\text { manufacturing sector }\end{array}$ & $\begin{array}{l}\text { The aim of the scheme is to increase competitiveness of MSMEs through } \\
\text { design and hence spread awareness on importance of design and its } \\
\text { learning. }\end{array}$ \\
\hline 6 & $\begin{array}{l}\text { Marketing Assistance \& } \\
\text { Technology Up-gradation } \\
\text { Scheme }\end{array}$ & $\begin{array}{l}\text { This scheme is basically an initiative of GOI in order to adopt the modern } \\
\text { marketing techniques by SMEs }\end{array}$ \\
\hline 8 & $\begin{array}{l}\text { Technology and Quality Up- } \\
\text { gradation Support to MSMEs }\end{array}$ & $\begin{array}{l}\text { This scheme enhances the use of energy based technologies in } \\
\text { manufacturing sectors in order to reduce the production cost and adopt } \\
\text { clean development mechanism. }\end{array}$ \\
\hline improvement and Yojana & $\begin{array}{l}\text { The objective of the scheme is to train personnel for the cadres of } \\
\text { supervisors/instructors/artisans to meet the requirement of skilled man- } \\
\text { power for the development of SMEs }\end{array}$ \\
\hline
\end{tabular}

\section{STATUS QuO OF INDIAN SMES}

Numbers of SMEs in India are continuously increasing every year. As per data available from Indian equity brand foundation, the numbers of SMEs are increased from 5008 to 7735 from FY07 to FY 11. The rate of increase of the same on yearly basis is shown as under. And as per available data from Ministry of micro small and medium enterprise 55\% of SMEs are situated in urban part where as remaining $45 \%$ is established in the rural part of India. Contribution of these SMEs is 16\% in repair and maintenance, $17 \%$ in service sector and $67 \%$ in the manufacturing sector. Even though the Indian SMEs are facing various challenges such as unavailability of modern technology, lack of infrastructural facilities, unavailability of skilled workers etc.



Fig. 1: Increase in number of SMEs

(Source: Ministry of micro small and medium enterprise) 




Fig. 2: lacking in basic infrastructural facilities

(Source: Ministry of micro small and medium enterprise)

Figure 3 highlights some of the key issues that enterprises face because of inflexible labor laws. The majority of enterprises (84\%) feel that retaining talent is the biggest challenge due to lack of ability to pay well and inadequate employer branding. The challenge that fared lowest amongst respondents was unavailability of skilled workers at affordable costs, $77 \%$ enterprises felt this was a challenge. Even low productivity of labor and lacking of minimum wages policy are also among the major reasons for the lacking of Indian SMEs on manufacturing as well as economic fronts.

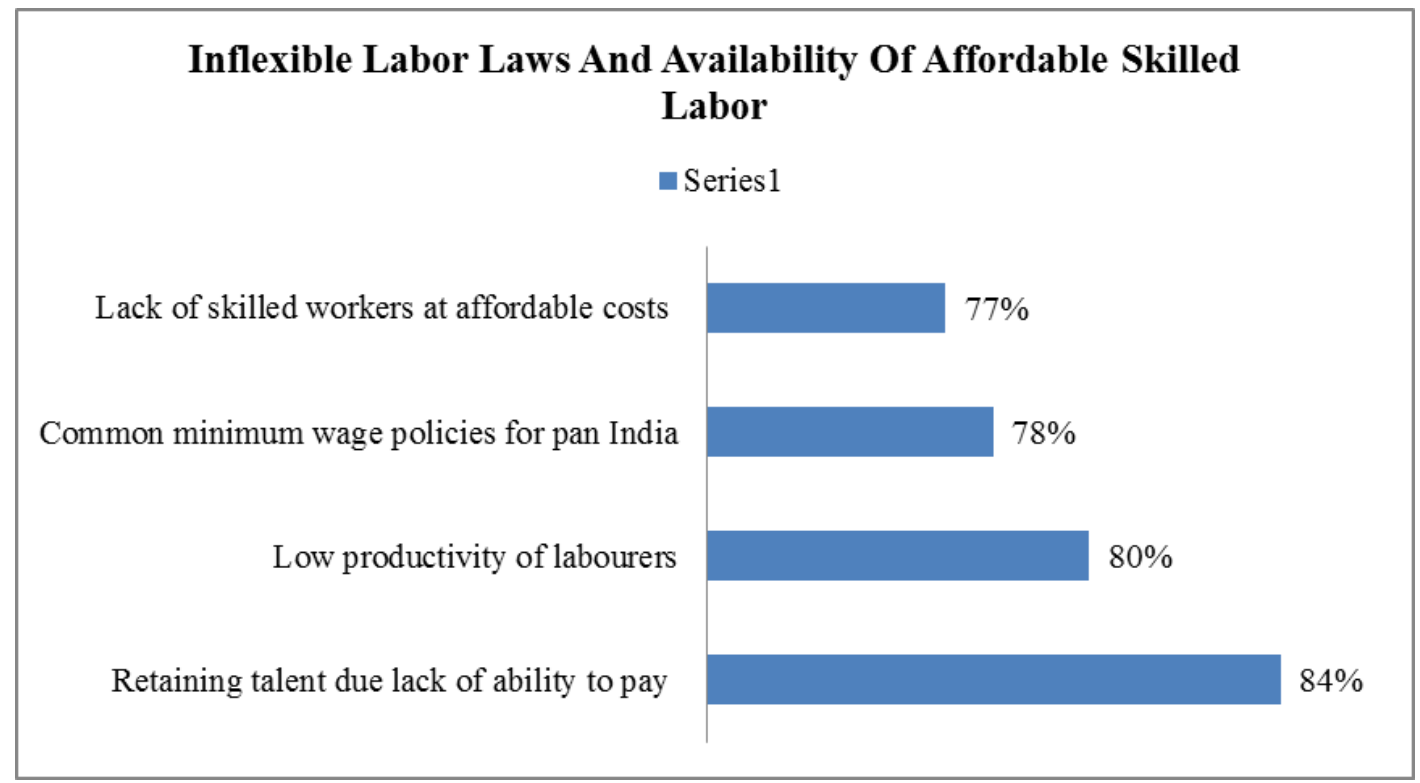

Fig. 3: Inflexible Labor Laws and Availability of Affordable Skilled Labor (Source: Ministry of micro small and medium enterprise)

\section{Challenges BEFORE LEAN SiX SigMa IMPLEMENTATION}

As far as LSS is highly profitable technique in America, but India is facing a number of challenges for its implementation such as : Un skilled workers, Less awareness about LSS: Afraid of getting company culture effected, Supply Chain Issues, Employee Development and other Technological Challenges. Approximately 30 per cent of Indian SMEs have applied LSS in its business and the remaining 70 per cent are not yet engaged with LSS initiative for a number of reasons (Antony and Banuelas, 2002). Satisfaction with other quality and productivity improvement initiatives turned out to be the strongest reason for not embarking on LSS program, 
followed by lack of awareness and unsuitability of the initiative to their type of business (refer figure 4 for details).

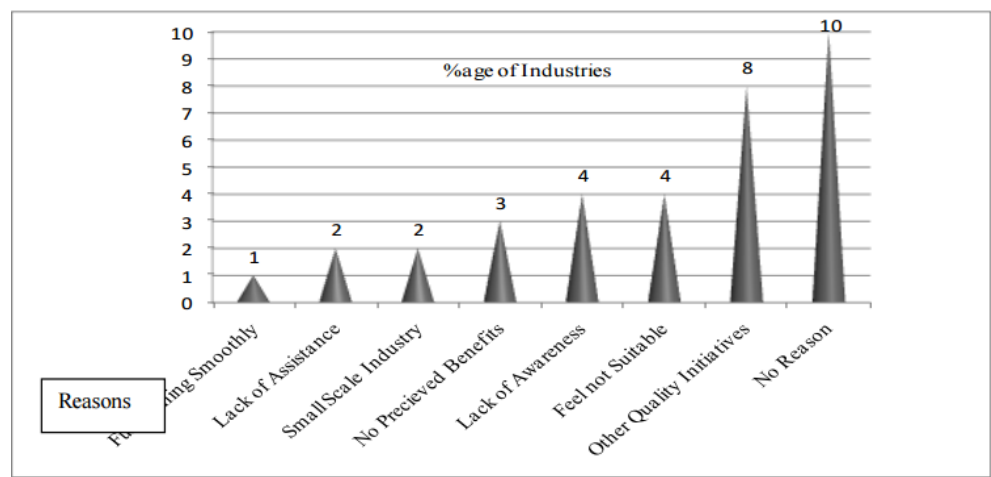

Fig. 4: Reasons for not adopting LSS

(Source: Antony and Desai, 2009)

\section{LITERATURE REVIEW}

Thorough literature survey has been carried out to capture the voice of concerned people and their relevant works as far as implementation of Lean six sigma in various (Large, Medium and Micro) industrial organizations are concerned. Literature based upon waste management has been reviewed and it reviles that waste is having a great significance on the economic losses bared by an industrial organization. Uma (2013) discussed that waste reduction in Industrialization is a very effective means for solving the problems related to economic and social progress as far as developing countries of the world are concerned. Myrdal (2013) has rightly described the relationship between industrialization and economic development when he observes that "the manufacturing industry represents, in a sense, a higher stage of production in advanced countries". Vinesh(2012) describes that in modern environmental legislation is becoming much more internationally coherent and less prescriptive, and focused on prevention of pollution through control of hazardous materials and processes as well as on protection of eco-systems. Garish(2012) purposed Value Stream mapping technique involves flowcharting the steps, activities, material flows, communications, and other process elements that are involved with a process or transformation showing significant effect of wastage on industrial economies. Tamizharasi (2014) discussed about various waste management techniques used in Indian MSME suggested benefits of implementing lean concept and focuses on Value Stream Mapping (VSM) and Single Minute Exchange of Dies (SMED) in Carriage Building Press shop. Kumar (2014) identified various Lean manufacturing systems acknowledged by Indian industry as a capable system in enhancing organizational performance by focusing on elimination of waste from the manufacturing system and thus improving effectiveness of the organization. Kumar (2014) examined that efforts have been made to identify the barriers for lean implementation and then to develop the relationships among these identified barriers. Literature of various people who worked upon Lean Six Sigma has been reviewed and brief summery has been illustrated below. Prieto-avalos (2014) studied that Lean manufacturing provides an approach to identify and eliminate waste and all non-value added activities through continuous improvements. Thanki (2014) concluded a report of pilot study on LSS awareness and implementation using the survey data collected from about 32 industries situated in western and eastern region of India. A survey instrument containing 45 statements was designed to assess respondents' attitude and awareness toward lean practices and to explore the level of lean implementation in the organization. Naveen (2013) indicated that The requirement of Lean six sigma manufacturing has increased due to waste and subsequent increase in cost of the manufacturing goods.

\section{RESEARCH GAPS}

After thorough literature review it has been found that reduction of scraps can play a key role in in order to maximize the profits of Indian SMEs. In past number of waste reduction techniques has been utilized by various researches such as TQM, Quality control, JIT, KAIZEN, 5S, Lean Manufacturing, Six Sigma etc. But it 
has been observed that these techniques are lesser effective to give the desired results due to various reasons. As generally product oriented approaches are found, instead of process oriented scrap management techniques. Lean Six sigma is a scrap reduction technique which is quite widely utilized in American states at present, and good results are reaped after its proper implementation. But from literature survey it has been observed that LSS is very rarely used technique in Indian industrial environment. Therefore there is a huge scope of implementing LSS technique in Indian SMEs and to notice the subsequent changes. From reviewed literature it has been observed that there is no standard procedure for the implementation of Japanese techniques in the industries. Even there is lack of professional approach to fight for waste management. Proper training to Green belt, Yellow Belt \& Back Bely is required as well as further training of the work force can be done in order to implement the LSS.

\section{REFERENCES}

[1] Abreu TS., Almeida GM., and Luis DR., "A framework for assessing the use of lean production practices in manufacturing cells" International Journal of Production Research, 49, 11, 3211-3230.

[2] Adnan H., Rahman A. and Noordin M. "Boosting Lean Production via TPM" International Congress on Interdisciplinary Business and Social Science, 1(1), 2012, 485-491.

[3] Ajay K Solanki, Mit Pandya, Dhananjay Bisht, "Lean Manufacturing Application on Welding Defects in Cryogenic Vessel" International Journal of Emerging Technology and Advanced Engineering, 4(10), 2014, 562-566.

[4] Akhil kumar, "A Qualitative Study on the Barriers of Lean Manufacturing Implementation: An Indian Context (Delhi Ncr Region)", the International Journal of engineering and Science, 3(4), 2014, 21-28.

[5] Antoni J., and Desai, “Critical failure factors of Lean Six Sigma: a systematic literature review”, IJQRM, 31(6), 1012-1030.

[6] Awasare and Kavade "A Review of Assembly Line Changes for Lean Manufacturing" IOSR Journal of Mechanical and Civil Engineering, 3(2), 2014, 01-05.

[7] Bowman, H. Edward and H. Dillep, "Strategy Through the Option Lens: An Integrated View of Resource Investments and the Incremental-Choice Process", Academy of Management review, 18(4), 1993, 760-782.

[8] H.L. Correa, "Linking Flexibility, Uncertainty and Variability in Manufacturing Systems: Managing Unplanned Changes in the Automotive Industry" Avebury, London, 1994.

[9] D'Aveni R. Hyper competition: Managing the Dynamics of Strategic Maneuvering, (The Free Press: New York, 1994).

[10] G.S. Dangayach, and S.G Deshmukh, "Manufacturing Strategy Perspective on Flexibility: A Case of Select Indian Companies" Global Journal of Flexible Systems Management, 2(2), 2001, 21-30. 